\title{
Malaria in Colombia: Retrospective Glance during the Past 40 Years
}

María V. Valero-Bernal

B. Sc. Bacteriología. M. Sc. en Epidemiología de Enfermedades Comunicables. Ph D. (Candidata) Salud Pública. Dpto Medicina Interna, Universidad Nacional de Colombia. E-mail: mvvalerober@unal.edu.co

Received $5^{\text {th }}$ Jun 2006/Sent for Modification $14^{\text {th }}$ September 2006/Accepted $22^{\text {th }}$ October 2006

\begin{abstract}
Objective Describe and analyze the structural configuration of malaria in Colombia since 1960 to 2004 where the phenomena of persistence, resurgence and resistance as well as the main determinants associated to these phenomena.

Methods A comparative study of the history of malaria and its trend was conducted in Colombia since 1960-2004. Secondary and primary information about the frequency and spatial distribution of malaria was collected. The sub period were identified according to institutional transformation and malaria control strategies as well as the socioeconomic and sociopolitical conjuncture factors in the country.

Results The structural and situational analyses of malaria in Colombia shown a steadily increase in morbidity from an average API 2,19 x 1000 in 1960-74 to 8,92 by $1994-2004$. Since the middle 70 's there has been a considerable reduction of mortality. The malaria case relation $P$. vivax vs. $P$. falciparum is 3 to 5 , respectively. The Annual Positive Sample Rate increased during the same study periods from 3,96\% to $29,93 \%$. Unfortunately the Annual Blood Examination Rate-ABER decreased by fewer than $5 \%$, instead of increase to minimum required for detection of malaria.

Conclusions During the National Eradication Malaria Service the malaria decreased steadily by the first five years, unfortunately the disease present resurgence, persistence after the reduction of financial and technical support from international health agencies in the middle seventies. Nowadays, around $85 \%$ of the territory, mainly rural areas are endemic for malaria. In spite of the transformation of the health system and different strategies implemented against malaria, it continues being one of the priorities in the public health services of Colombia.
\end{abstract}

Key Words: Malaria, control, transmission, Colombia (source: MeSH, NLM) 


\section{RESUMEN \\ Malaria en Colombia: Mirada retrospectiva a los últimos 40 años}

Objetivo Describir y analizar la configuración estructural de malaria en Colombia desde 1960 a 2004 considerando los fenómenos de persistencia, resurgimiento y resistencia y los principales determinantes asociados. Métodos Se realizo un estudio comparativo de la historia de malaria y su tendencia en Colombia desde 1960-2004. Se realizo una búsqueda de información primaria y secundaria sobre la frecuencia y la distribución espacial de malaria. Los periodos fueron identificados según la transformación institucional y estrategias de control/erradicación de malaria así como elementos coyunturales socio-económicos y sociopolíticos asociados al mismo periodo de estudio.

Resultados. El análisis estructural y situacional de la malaria en Colombia muestra un considerable aumento en la mortalidad de IPA de 2,19 1000 en 1960-74 a un IPA de 8,9 entre 1994-2004. Desde mediados de los 70 ha habido una reducción considerable de mortalidad. La relación de caso de malaria de $P$. vivax versus $P$. falciparum es 3 a 5, respectivamente. El Índice Anual de Muestra Positiva aumentó durante los mismos períodos del estudio de 3,96 \% a 29,9\%. Sin embargo, el Índice Anual de Muestras Examinadas disminuyó por debajo del $5 \%$, manteniendo los valores mínimos requeridos para el control.

Conclusiones. Durante el Servicio de Erradicación de la Malaria la malaria disminuyó durante el primer ciclo. Desafortunadamente se presento el resurgimiento y persistencia desde mediados de los setenta después de la reducción de apoyo financiero y técnico de las agencias de salud internacionales. Actualmente, en el $85 \%$ del territorio, principalmente en áreas rurales, la malaria es endémica. A pesar de la transformación del sistema de salud y las estrategias implementadas contra la malaria, ésta continúa siendo uno de las prioridades en los servicios de salud pública de Colombia.

Palabras Clave: Malaria, control, transmisión, Colombia (fuente: DeCS, BIREME)

$\mathrm{M}$ alaria is an enormous challenge for the public health servicesof most of low and some middle income countries. This tropical disease has a significant effect on human capital accumulationand is very close related to areas with scare economical development and region with a considerable amount of people under the line of poverty (1). Moreover malaria has a higher negative impact on vulnerable groups such as pregnant women, children under 5, rural populations and populations in forced displacement $(2,3)$. 
This entails that malaria and poverty are intimately associated. This is not the same as saying poverty causes malaria or is a consequence of malaria, is quiet know that several structural factor of the society are implied as well ecological systems (4-7).

Several micro and macro social determinants have been associated to an increase on resistance of parasites and vector as well as the resurgence and persistence of malaria (8). The millennium report mentions four overarching reasons related to why the Goals are not being achieved: "Sometimes the problem is poor governance, marked by corruption, poor economic policy choices, and denial of human rights. Sometimes the problem is a poverty trap, with local and national economies too poor to make the needed investments"(9). But in malaria is also clear that health system reforms and breakdown of control programs; complex natural emergencies, intensive armed conflict and internally displaced people and collapse of local primary health services are widely associated (10-12).

Colombia does not escape to the international context and ranks among countries with highest malaria incidence of the Americas. There is a relatively high proportion of $P$. vivax cases but with $P$. falciparum as most pathogenic. The malaria problem is located in areas under 1800 meters of altitude. The endemic territory was reduced from $93 \%$ to $85 \%$ due to DDT spraying in the malaria eradication campaign. In 2005, 107866 malaria cases were recorded by the National Surveillance System_SIVIGILA, 46771 cases of $P$. falciparum and 79101 cases of $P$. vivax (13).

The neo liberal globalization has increased the inequities and impacted the primary structure of the society and institution of the state, with particular negative effects on public health functions, decentralization and inadequate implementation of programs of control, due mainly to scare capital human and reduction of financial budget at regional level. The evidence suggests that the new health system and the VBD Programme have not managed to confront prior trends (14). Endemic areas in Colombia are mainly rural with considerable differences in social security coverage, education, employment and land distribution (15).

In spite of the efforts to update and maintain the surveillance system of malaria there is few studies published about the malaria trends in Colombia during the last forty years. This study present a retrospective analyses of malaria considering thee historical periods associated to transformation of the institution and activities to combat malaria as well as conjuncture 
socioeconomic and political determinants. The increase on incidence of malaria between since 1960 to 2004 is considerably high and the efforts most be redirect because of the 31 departments reporting malaria 19 (61\%) present moderate and high risk of transmission. These means that malaria is persistent and has resurged in Colombia by the last two decades.

\section{METHODS}

The study includes 31 of the 33 administrative political division of the country reporting malaria since 1960 to 2004. The data analyzed consider all the cases positively confirmed by the health services in charge of the diagnostic according to National policy in three periods which are shown in Table 1.

Table 1. Structural and Institutional Transformation of malaria programs

\begin{tabular}{|c|c|c|c|c|c|}
\hline Period & $\begin{array}{l}\text { Health } \\
\text { System }\end{array}$ & Malaria & $\begin{array}{c}\text { Malaria } \\
\text { Institutions }\end{array}$ & $\begin{array}{l}\text { Type of } \\
\text { Structure }\end{array}$ & Main Activities \\
\hline $\begin{array}{l}1960 \\
1974\end{array}$ & SSI & Eradication & NMES & Vertical & $\begin{array}{l}\text { DDT House } \\
\text { Spraying, ACD, } \\
\text { treatment }\end{array}$ \\
\hline $\begin{array}{l}1974 \\
1993\end{array}$ & $\mathrm{NSH}$ & Eradication & AUDC & $\begin{array}{l}\text { Vertical } \\
1986 \\
\text { Decentralization }^{1}\end{array}$ & $\begin{array}{l}\text { ACD, PCD } \\
\text { Presumptive } \\
\text { Treatment } \\
\end{array}$ \\
\hline $\begin{array}{l}1994 \\
2004\end{array}$ & GSSSH & Control & VBD & $\begin{array}{l}\text { Horizontal depending } \\
\text { from national level. } \\
\text {-1998 } \\
\text { decentralization }{ }^{2} \\
\text { according to } \\
\text { municipal category }\end{array}$ & $\begin{array}{l}\text { Early Diagnose } \\
\text { and Prompt } \\
\text { treatment, } \\
\text { Vector Control } \\
\text { selective and } \\
\text { regulate. }\end{array}$ \\
\hline
\end{tabular}

1. Law 12, 1986 define the legal administrative decentralization. Malaria institution at Central and Departmental level change name but not the depending structure from central level. In 1990 and 1991, law 10 and 60, define the responsibilities; 2. Only after Law 100, 1993 and Law 715, 2001, is given the administrative and technical decentralization. Departments and municipalities assume public health functions according to the level of development; ACD: Active Case Detection; PCD: Passive Case Detection.

The information was collected from secondary and primary sources. Primary information refers to documents published or unpublished (gray) on malaria distribution and frequency during the period of the study. Besides, additional bibliometry material was obtained interviewing malariologists who worked in the malaria institutions since 1965 to 2004 at National or regional level. The secondary information corresponds to excel databases obtained from the Ministry of Health, Public Health Section and National Institute of Health.

The databases were manually correlated and compared to identify inconsistencies between different sources in case to be necessary. The 
denominator was the number of people at risk per year according to the guidelines of the national malaria program and manually correlated with the census projections from the National department of Statistics of Colombia, DANE.

Data analysis and processing

The information was captured in Excel by each year and Department. The following indexes were calculated by total country and the 31 departments:

Annual Parasite Incidence (API): total microscopically confirmed cases over the population at risk by year $\mathrm{x} 1000$

Annual Falciparum Incidence (AFI): falciparum microscopically confirmed cases over the population at risk by year $\mathrm{x} 1000$

Annual Vivax Incidence (AVI): Vivax microscopically confirmed cases over the population at risk by year

Annual Blood Examination Rate (ABER): number of blood slides read over population at risk $x 100$ by year

Slide Positive Rate: Number of positive blood slides over total blood slides taken $\mathrm{x} 100$

For each period and average of the indicators above mentioned was estimated. It was assumed that malaria control program structure and institution were modified on the dates mentioned.

The information from Excel was captured in GISepi Software from PAHO, and the spatial distribution presented by quintiles. During the same periods of analyses the proportion of departments at low, moderate and high risk were identified.

\section{RESULTS}

On the first period, 1960-1974 the predominant structure was the malaria eradication services. The territory was divided in 18 zones according to particular eco epidemiological conditions. The second period, 1975-1993, correspond to a new structure of the malaria eradication program but depending on central level. This coincides with the National Health System of Health and Primary Health Care implementation. At this point of time the EMS was transformed on the Division of Direct Campaign. The third 
period, 1993-2004, is known as the Vector Born Disease control Program under the responsibility of the Secretariat of Health at departmental level.

The annual parasite incidence of malaria shows a considerable increase when is compared by periods. The first period, presents an average API of 2,14 x 1 000 , and a positive slide rate of $3,97 \%$. The percentage of slides of fever cases examined to detect malaria on population at risk was only 5,6 \%. During the second period, the average API increased twice, but there was a considerable reduction in the annual blood examination rate. The third period shows the highest API, five times higher than in 60's a similar ABER but a statistically increase on SPR near 300\% the first period, and ten times the first one.

Table 2. Malaria Indicators by historical periods in Colombia, 1960-2004

\begin{tabular}{|c|c|c|c|c|c|c|}
\hline Period & $\begin{array}{c}\text { Malaria } \\
\text { Program }\end{array}$ & $\begin{array}{c}\text { Pop at Risk } \\
\text { Mean }\end{array}$ & $\begin{array}{c}\text { Blood } \\
\text { Smear Mean }\end{array}$ & $\begin{array}{c}\text { API } \times 1000 \\
\text { Mean }\end{array}$ & $\begin{array}{c}\text { ABER \% } \\
\text { Mean }\end{array}$ & $\begin{array}{c}\text { SPR } \\
\%\end{array}$ \\
\hline $\begin{array}{l}1960 \\
1974\end{array}$ & $\begin{array}{l}\text { Eradication } \\
\text { NMES }\end{array}$ & 11330134 & 626328 & 2,1 & 5,65 & 3,97 \\
\hline $\begin{array}{l}1975 \\
1993\end{array}$ & $\begin{array}{c}\text { Eradication } \\
- \\
\text { AUDC }\end{array}$ & 18432921 & 483873 & 4,6 & 2,6 & 17,3 \\
\hline $\begin{array}{l}1994 \\
2004\end{array}$ & $\begin{array}{l}\text { Control - } \\
\text { VBD }\end{array}$ & 20289379 & 554211 & 8,9 & 3 & 29,9 \\
\hline
\end{tabular}

The departments are classified by period and level of risk. In around 15 (48\%) of departments malaria is persistent with API equal or highest to 10 cases x 1000 since 1960 in Cordoba, Antioquia, Meta, Nariño, Cauca, Choco, Valle, Caqueta, Putumayo, North Santander between others. Since the constitution of 1991 the departments of Arauca, Guaviare, Guania, Vaupes, Vichada were officially conformed. These departments were originally part of departments conformed since 1886 constitutions or by decrees in middles 50's. The Department of La Guajira shows epidemic outbreaks. Approximately 11 (35\%), records moderate or low risk since 1960 till 2004, which means that under determined conditions malaria resurge or re emerge. Table 3 show an invariable trend in the number of endemic departments according to the level of risk since 1960 till 2004.

Table 3. Departments with malaria according to level of risk

\begin{tabular}{lccccc}
\hline Level Of Risk & $1960-63$ & $1964-74$ & $1975-85$ & $1986-95$ & $1996-2004$ \\
\hline Low & 3 & 15 & 9 & 10 & 12 \\
Moderate & 18 & 15 & 13 & 6 & 5 \\
High & 10 & 1 & 9 & 15 & 14 \\
\hline Low API: < 1 case $\times 1000 ;$ Moderate API: $1-10$ cases $\times 1000 ;$ High: >10 cases $\times 1000$ &
\end{tabular}




\section{DISCUSSION}

The surveillance coverage in the population at risk measured indirectly by the ABER has been constant during the last 44 years and do not overpass the $5 \%$ instead of the $10 \%$ which is the minimum required for detection of malaria. However the SPR increased 25 times and presents a positively trend to the increment $\left(\mathrm{R}^{2}=0.852\right)$ (Figure 1$)$. This suggests clearly resurgence of this pathology with weak possibilities of control. Also the reduce capacity of access and coverage by the system of health.

An additional and interesting interpretation is that $90 \%$ of cases are registered from rural endemic areas which present the extreme poverty and malnutrition and impossibility to access health services. During the last 3 years Colombia has presented a considerable reduction on the rural rate, from $60 \%$ in 60 's to $26 \%$ in 2004 . The rate of growth also decreased an is around 1,2 \% over the last decade. This means that population migrate to urban areas looking for better conditions of life, health access and education. Unfortunately people still living in rural areas have not been benefit of agrarian

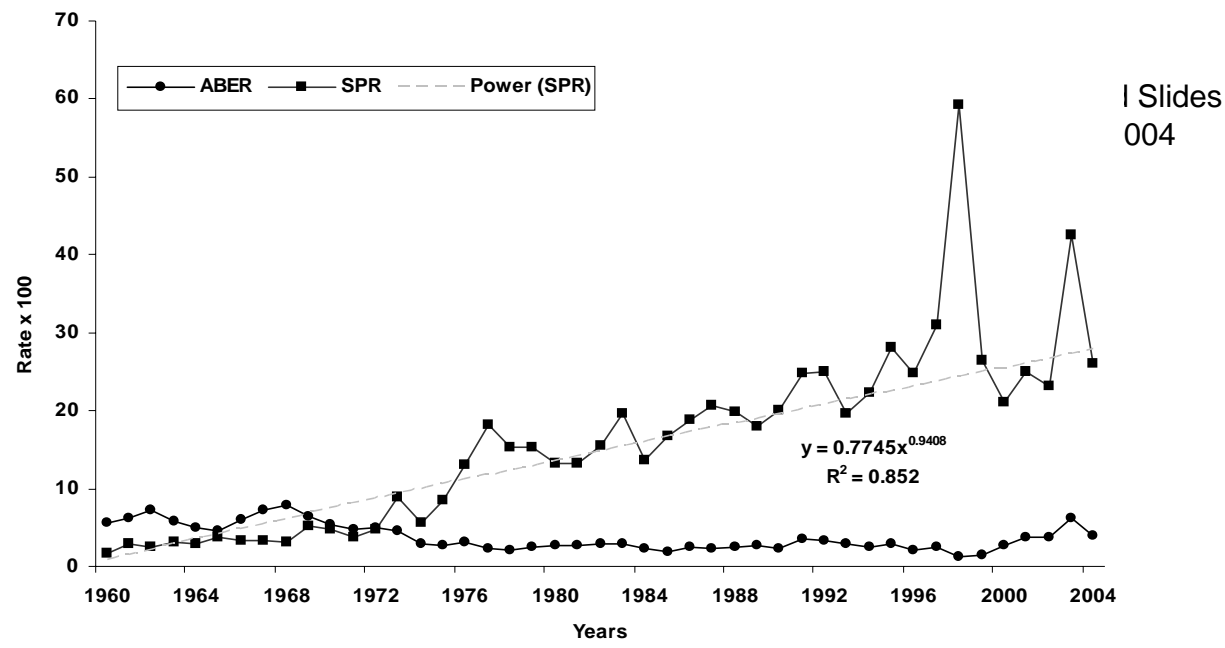


On the other hand, the adjust of agrarian sector without any kind of subsidized within the context of the current globalization intensified the rural poverty. The national poverty by 1978 was $80 \%$ and by $200167 \%$. Unfortunately this was a little different for rural population in 90's decade. At the beginning of 90s the poverty was around $68 \%$ and finalizing the decade increased 10 percentage points, i.e. $83 \%$ in relation to the urban counterpart (16). In addition the rural population that still live in those areas do not have improved the incomes and maintain lowers level of quality of live.

This problematic is evidenced on educational sector in spite of being constitutional right. The average of education years in 1950, 1973 and 1992 was 2,6, 49,1 and 9,1 respectively. In spite the growth up trend, the main problem in rural areas is to retain and promote students to highest levels: for each 100 students on the first year of primary school only 35 complete the cycle and only 16 of them continue in high school studies. But only 7 of then settle the high school cycle (17).

There are considerable differences between the urban and the rural. The indicators of human development of PNUD 2003, shows that inhabitants from rural zones lives in average $2 \mathrm{yrs}$ less than those from urban zones. The per capita incomes is twice higher in urban than in rural. Two conditions complement the dark panoramic view: the low coverage of the General Social Security System, specially the health sector and the high levels of malnutrition and anemia of infant population. The anemia in the age group $1-4$ yrs is $30,8 \%$ in urban vs. $39,1 \%$ in rural (17).

Finally, in rural areas the agropecuarian employment increases but not the nonagropecuary; it was reduced in 390000 and the salaries decreased. Given that malaria is concentrate in a $95 \%$ in rural areas the strategies of control whichever their origin must be accompanied of reduction of poverty levels and agrarian reforms to strength and improve the quality of life of people living in those rural and distant areas. It will content not only the economic aperture but also reduce malaria burden and other communicable diseases of the poors.

Acknowledgements. This study was a collaborative effort with several professors and friends at the Universidad Nacional de Colombia, Bogotá and Swiss Tropical InstituteUniversity of Basel, Switzerland. This study was financial supported by the Research Training Grants \& Fellowships Special Programme for Research \& Training in Tropical Diseases (TDR) ID No.30976 and Division de Investigación, Universidad Nacional de Colombia, Bogotá (DIB) 20201005260 de 2004. 


\section{REFERENCES}

1. Sachs J, Malaney P. The economic burden of malaria. Nature. 2002; 415(680-85).

2. Sharma V. Malaria and Poverty in India. Current Science. 2003; 84(4): 513-15.

3. World Health Organization. Enhancing health Systems: Malaria's Negative Impact in Africa. ESPD, Poverty and Social Policy Team. Geneva; 2005. p. 40.

4. Breman J. The ears of the hippopotamus: manifestations, determinants, and estimates of the malaria burden. American Journal of Tropical Medicine and Hygiene. 2001; 64(1,2): 1-11.

5. Zaidi S. Poverty and Disease: Need for Structural Change. Soc. Sci. Med. 1988; 27(2):119-27.

6. PNUD. Informe Sobre el Desarrollo Humano. UNDP (Ed.). New York, EUA: UNDP; 1999. p. 100.

7. Granados-Torano R. Reformas Neolibreales de los Sistemas de Salud. Facultad Nacional de Salud publica Carlos Finlay. La Habana: Instituto Superior de Ciencias Medicas de La Habana: 2001 p. 3000.

8. Tolhurst R. Vulnerability to Malaria in Ghana: Health Policy and Access. Alliance for Health Policy and System Research. Geneva; 2003. p. 23.

9. Bank W. Investing in Development. A Practical Plan to Achieve the Millenium Development Goals. Chapter 3: Why the world is falling short of the Goals? Geneva; 2005. p. 28-52.

10. Worral E, Basu S, Hanson K. Is malaria a disease of poverty? A review of literature. Tropical Medicine and International Health. 2005; 10(10):1047-59.

11. Stephens D.S. Emerging and reemerging infectious diseases: a multidisciplinary perspective. Am J Med Sci. 1998; 15(2): 64-75.

12. D’Alessandro U, Burtiens H. History and importance of antimalaria drug resistance. Tropical Medicine and International Health. 2001; 6(2): 845-848.

13. Zambrano P. Informe Final de Malaria. Semana 1 a 52. Inf Quinc Epidemiol Nac. 2006; 11(4): 49-53.

14. Agudelo CA, Corredor A, Valero MV. Assessing options for an innovative malaria control programme on the basis of the experience with the new Colombian Health Social Security System. Rev. Salud Pública (Colombia). 2004; 6 (Sup. 1):1-39.

15. FAO. Perfiles Nutricionales por Países. En: Perfiles Nutricionales-Colombia, Roma: FAO; 2001. p. 35.

16. Montenegro-Trujillo S. Estimaciones de Pobreza e Indigencia en Colombia, 2005. Bogota: Dirección Nacional de Planeación; 2006. p. 20.

17. Perfetti M. Estudio sobre la Educacion para la Poblacion Rural en Colombia. P.F.-U.-D. Italia-CIDE-REDUC. (Ed.). Bogotá: Direccción Nacional de Planeacion; 2000. p. 35. 